\title{
www.casopoismapan.p. PAN 级定 \\ Isothermal Transformation Ar1 Product Morphology and Kinetics of EN-GJS-600-3 Cast Iron
}

\author{
T. Szykowny, T. Giętka *, K. Ciechacki, L. Panfil, L. Romanowski \\ Department of Materials Science and Engineering, Mechanical Engineering Faculty, \\ University of Technology and Life Sciences, Prof. S. Kaliskiego 7, 85-796 Bydgoszcz, Poland \\ *Corresponding author. E-mail address: tgietka@utp.edu.pl
}

Received 22.06.2016; accepted in revised form 28.09.2016

\begin{abstract}
This work presents the qualitative and quantitative changes in the products of isothermal transformation (reaction) in a ductile cast iron austenite after supercooling to the temperature range $\mathrm{A}_{\mathrm{r} 1}$. The austenitizing temperature considered in this work was 900,960 or $1020^{\circ} \mathrm{C}$. The eutectoid reaction was investigated by metallographic examination at a holding temperature right below $\mathrm{A}_{\mathrm{r} 11}\left(820^{\circ} \mathrm{C}\right)$ or right below $A_{r 12}\left(760^{\circ} \mathrm{C}\right)$. The quantitative metallographic examination was carried out with a light microscope (LM). The initial transformation stage products were identified with a transmission electron microscope (TEM). The selected samples were studied for chemical microsegregation of manganese, silicon, phosphorus, and carbon with an X-ray microanalyser (MAR). The tested cast iron material was found to predominantly feature a eutectoid reaction in the metastable system the ratio of which was increasing with the austenitizing temperature. The austenitizing temperature was found to be conducive to the evolution kinetics of individual phases and to the graphitization kinetics of the eutectoid cementite that was formed during the contemplated reaction.
\end{abstract}

Keywords: Spheroidal cast iron, Isothermal eutectoid reaction, Transformation kinetics

\section{Introduction}

Non-alloy grey cast iron has a structure that features austenite and graphite at temperatures above $\mathrm{Ac}_{12}$. The austenite saturation with carbon is a function of the austenitizing temperature and the cast iron chemical composition [1-5]. The austenite carbon saturation value is the abscissa of the austenitizing temperature isothermal line intersection with the E'S' line on the polythermal equilibrium chart of a Fe-C-Si pseudo-binary system [6]. Precooling the cast iron down to the temperature range $\mathrm{A}_{\mathrm{r} 1}$ with isothermal holding results first in precipitation of surplus carbon, which is necessary to initiate the eutectoid reaction. Depending on the tendency for solid cast iron graphitization, surplus carbon precipitation may occur in a stable system or a metastable system [6]. In the stable system, the austenite precipitates secondary graphite on the existing graphite nodules and this forms a metallographically identifiable layer [7]. In the metastable system, where there is a low tendency for graphitization and the austenite features a high input carbon level, the carbon is precipitated as secondary cementite. The precipitate forms a network $[4,5,8]$. The surplus carbon may also precipitate from supercooled austenite both in stable and metastable systems. The pre-eutectoid carbon precipitation as secondary cementite is generally considered to be detrimental. Only when the supercooled austenite concentration to temperature point is below the approximated line GS' do thermodynamic conditions exist that enable eutectoid reaction. The eutectoid reaction may be in a stable or metastable system, 
depending on the supercooling rate, cast iron chemical composition, and pre-eutectoid precipitate types [6]. The eutectoid reaction is most likely to follow both systems in supercooling of non-alloy ductile cast iron austenite. The majority of reference literature suggests that the austenite $\rightarrow$ ferrite + graphite transformation has priority over the austenite $\rightarrow$ pearlite transformation [9-15]. The objective of this work is to demonstrate and interpret the effect of austenitizing temperature on the nature of pre-eutectoid precipitates and the eutectoid reaction kinetics separately for the stable system and the metastable system in cast iron with a low solid graphitization trend. A secondary objective is to trace the eutectoid cementite graphitization (intermediate graphitization) kinetics. The capacity for achieving a preset quantitative ratio of (divorced) pearlite to ferrite during isothermal holding is a very attractive option for shaping a required set of mechanical properties in cast iron materials.

\section{Materials, program, and methodology}

The contemplated examination object was ductile cast iron with a relatively low tendency for solid-state graphitization, defined by the isographitization factor $\mathrm{K}_{\mathrm{G}}$ " calculated according to the Giršovič formula [16]. The cast iron composition is shown in Table 1.

Table 1.

Cast iron chemical composition

\begin{tabular}{cccccccc}
\hline \multicolumn{1}{c}{ Components in \% w/w } \\
\hline $\mathrm{C}$ & $\mathrm{Si}$ & $\mathrm{Mn}$ & $\mathrm{P}$ & $\mathrm{S}$ & $\mathrm{Cr}$ & $\mathrm{Cu}$ & $\mathrm{Ti}$ \\
\hline 3.53 & 2.72 & 0.98 & 0.061 & 0.013 & 0.02 & 0.07 & 0.021 \\
\hline $\mathrm{Mg}$ & $\mathrm{Al}$ & $\mathrm{Ni}$ & $\mathrm{Mo}$ & $\mathrm{V}$ & ${ }^{1)} \mathrm{S}_{\mathrm{c}}$ & ${ }^{2)} \mathrm{K}_{\mathrm{G}}{ }^{\prime \prime}$ \\
\hline 0.052 & 0.031 & 0.009 & 0.021 & 0.043 & 1.04 & 8.60 \\
\hline
\end{tabular}

${ }^{1} \mathrm{~S}_{\mathrm{c}^{-}}$eutectic saturation ratio, calculated per [6]

${ }^{2)} \mathrm{K}_{\mathrm{G}}$ " - isographitization constant, calculated per [16]

The cast iron was melted in a hot blast acidic liner cupola from a charge containing a haematitic crude and recycled ductile cast iron scrap. The cast iron was spheroidized in the cupola tank with an FeMgSi alloy and modified in the runner with a FeSi75 ferrosilicon. The cast iron was cast to wet sand moulds to replicate the YII samples. A tensile test was carried out on the cast iron material and made the material eligible as grade ENGJS-600-3, ref. PN-EN 1563:2012.

The eutectoid reaction temperature values were determined by dilatometry during continuous heating and cooling at a rate of $0.033 \mathrm{~K} / \mathrm{s}$ and are as follows: $\mathrm{A}_{\mathrm{c} 11}=795, \mathrm{~A}_{\mathrm{c} 12}=862, \mathrm{~A}_{\mathrm{r} 11}=774$, $\mathrm{A}_{\mathrm{r} 12}=685$. The initial graphitization temperature $\left(\mathbf{t}_{\mathbf{g r}}\right)$ of eutectoid cementite during the heating cycle $t_{g r}$ is $708^{\circ} \mathrm{C}$. The cast iron structure and mechanical properties are shown in Table 2.
Table 2.

Cast iron structure and mechanical properties

\begin{tabular}{ccccc}
\hline \multicolumn{3}{c}{ CI matrix, \% v/v } & \multicolumn{2}{c}{ Graphite } \\
\hline Ferrite & Pearlite & Cementite & $\mathrm{V}, \% \mathrm{v} / \mathrm{v}$ & ${ }^{1} \mathrm{~L}_{\mathrm{w}}, 1 / \mathrm{mm}^{2}$ \\
\hline 19.1 & 80.5 & 0.4 & 9.7 & 107 \\
\hline \multicolumn{5}{c}{ Mechanical properties } \\
\hline $\mathrm{R}_{\mathrm{p} 0.2 \mathrm{MPa}}$ & $\mathrm{R}_{\mathrm{m}} \mathrm{MPa}$ & $\mathrm{A}_{5}, \%$ & $\mathrm{HB}$ \\
\hline 476 & 610 & 3.5 & 241 \\
\hline
\end{tabular}

1) $\mathrm{L}_{\mathrm{w}}$ - Graphite precipitates count per $1 \mathrm{~mm}^{2}$ of microsection

The cast iron microstructure is shown in Fig. 1.

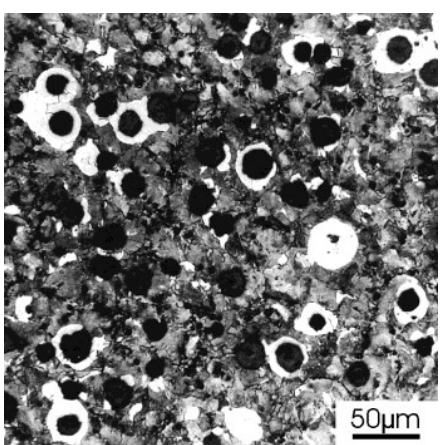

Fig. 1. CI structure, as cast, nital etched, LM

$\varnothing 20 \times 3 \mathrm{~mm}$ disks were cut out of the rectangular part of the YII casting and heat-treated according to the diagram in Fig. 2.

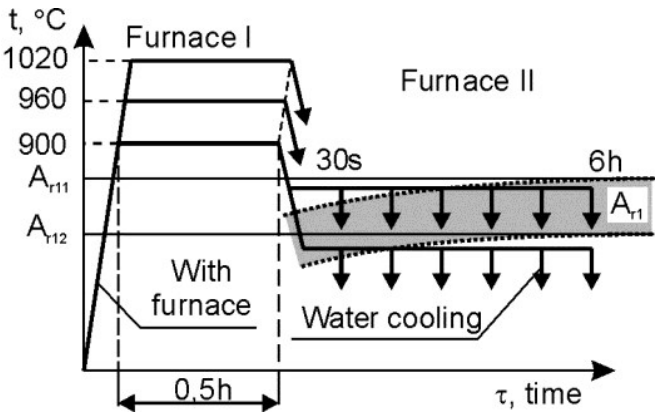

Fig. 2. Diagram of the CI heat treatment

Vertical pipe furnaces of the isothermal dilatometer were used for the heat treatment. The heating volume of the furnace was purged with purified argon. The microsections were produced from the samples processed as shown in Fig. 2. These were subject to a metallographic quantitative analysis. The initial stage transformation products were examined with a TEM, using a twostep replica of carbon shaded platinum.

\section{Research results and their analysis}

Austenitizing the cast iron at $900^{\circ} \mathrm{C}$ followed by holding at $820^{\circ} \mathrm{C}$ initiates the eutectoid reaction in a stable system. First, the ferrite $(\mathrm{F})$ is formed (Fig. 3a) and present as in the form of a polygonal grains against the austenite (martensite $\mathrm{M}$ ). A small amount of ferrite is formed at later stages (Fig. 3b) at graphite (G). 
A special characteristic of the cast iron austenitized at higher temperatures $\left(960^{\circ} \mathrm{C}, 1020^{\circ} \mathrm{C}\right)$ is the pre-eutectoid precipitation of secondary cementite which forms a network (Fig. 4a). The first product of eutectoid reaction is pearlite $(\mathrm{P})$, which nucleates and grows out from the boundary between the networked cementite $\left(\mathrm{C}_{\mathrm{m}}\right)$ and the austenite (Fig. $\left.4 \mathrm{~b}\right)$.
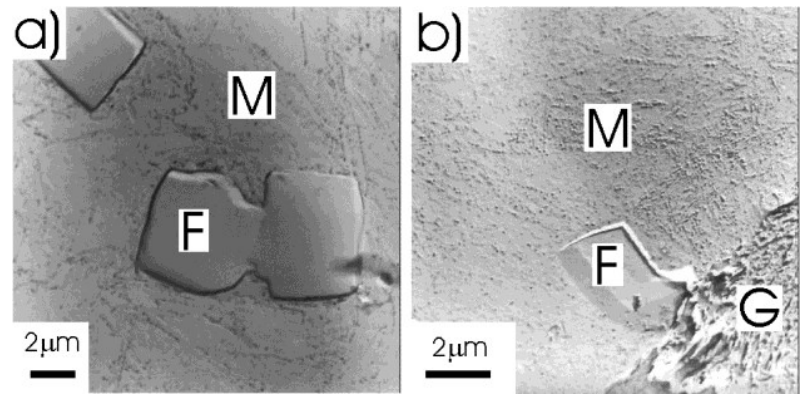

Fig. 3. Micrograph of cast iron austenitized at $900^{\circ} \mathrm{C}$ and held at $820^{\circ} \mathrm{C}$, duration (a) $1800 \mathrm{~s}$, (b) $3600 \mathrm{~s}$, TEM imaging
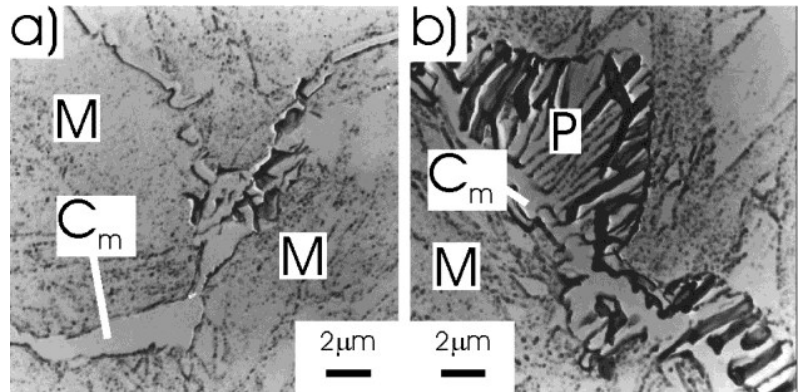

Fig. 4. Micrograph of cast iron austenitized at $1020^{\circ} \mathrm{C}$ and held at $820^{\circ} \mathrm{C}$, duration (a) $60 \mathrm{~s}$, (b) $240 \mathrm{~s}$, TEM imaging

The cementite network and the pearlite are not stable at temperatures approximate to $\mathrm{A}_{\mathrm{r} 11}\left(820^{\circ} \mathrm{C}\right)$. The network becomes fragmented over time, and the cementite particles are subject to spheroidization. The eutectoid (pearlite) ferrite transforms back into austenite, and the eutectoid cementite is subject to spheroidization. The microareas previously occupied by pearlite and the cementite network have now clusters of globular cementite grains against the austenite. The cementite nodules at the boundary areas of eutectic grains persist event after 6 hours of holding. The transformation reaction contemplated herein might cause the increase of cementite in heat-treated cast iron with eutectoid reaction, a phenomenon cited in reference literature [5, 17]. Ferrite is a stable product of eutectoid reaction. The cast iron austenitized at $960^{\circ} \mathrm{C}$ for 6 hours contains $1.2 \% \mathrm{v} / \mathrm{v}$ of ferrite, the grains of which are mostly without contact with graphite (Fig. 5).

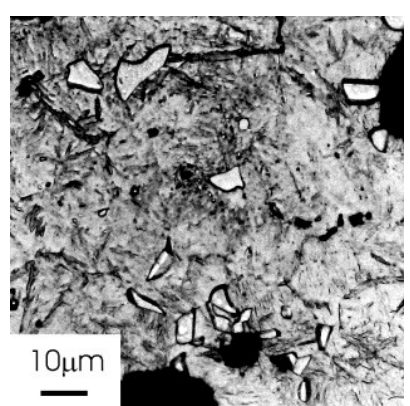

Fig. 5. Micrograph of cast iron austenitized at $960^{\circ} \mathrm{C}$ and held at $820^{\circ} \mathrm{C}$, duration: $6 \mathrm{~h}$, nital etched, $\mathrm{LM}$

The eutectoid reaction in the cast iron austenitized at $900^{\circ} \mathrm{C}$ and held at a temperature below $\mathrm{A}_{\mathrm{r} 12}\left(760^{\circ} \mathrm{C}\right)$ begins with the crystallization of pearlite in the eutectic grain boundary areas and the ferrite boundary areas at graphite (Fig. 6).
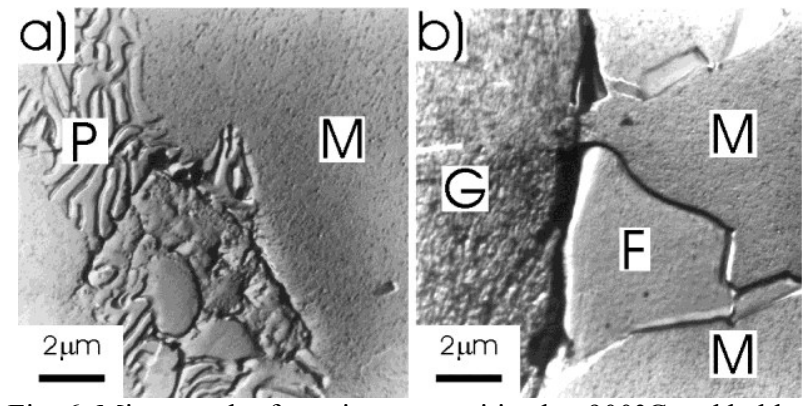

Fig. 6. Micrograph of cast iron austenitized at $900^{\circ} \mathrm{C}$ and held at $760^{\circ} \mathrm{C}$, duration (a) $120 \mathrm{~s}$, (b) $240 \mathrm{~s}$, TEM imaging, two-stage carbon replica

The cast iron austenitized at $960^{\circ} \mathrm{C}$ or $1020^{\circ} \mathrm{C}$ and held at $760^{\circ} \mathrm{C}$ displays initial precipitates of a pre-eutectoid (secondary) cementite network (Fig. 7a). The first product of eutectoid reaction is pearlite, which grows out from boundary between the secondary networked cementite $\left(\mathrm{C}_{\mathrm{m}}\right)$ and the austenite (Fig. $\left.7 \mathrm{~b}\right)$.

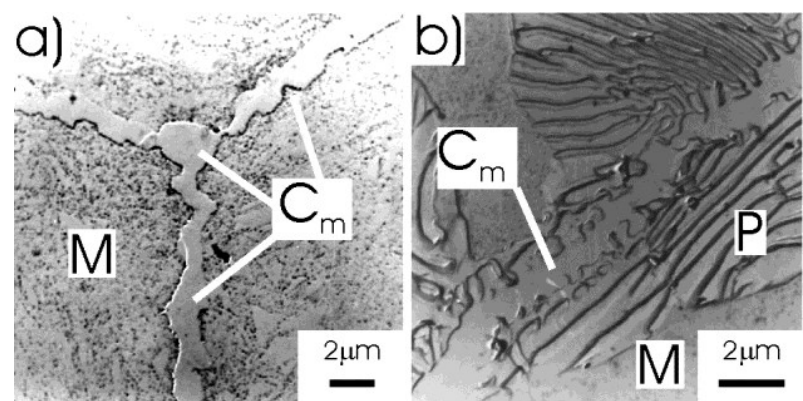

Fig. 7. Micrograph of cast iron austenitized at $1020^{\circ} \mathrm{C}$ and held at $760^{\circ} \mathrm{C}$, duration (a) $30 \mathrm{~s}$, (b) $240 \mathrm{~s}$, TEM imaging

The cementite network is unstable, and its fragmentation begins before the eutectoid reaction ends (Fig. 8). 

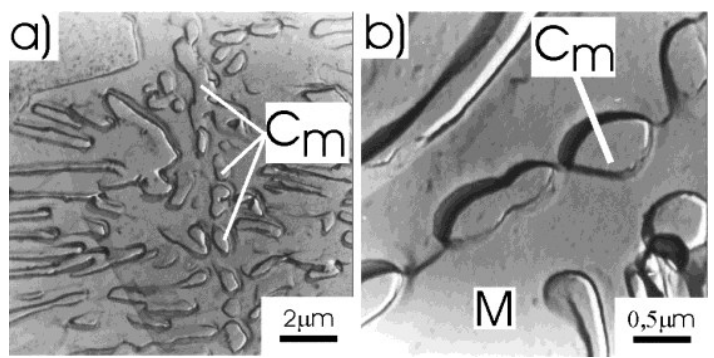

Fig. 8. Micrograph of cast iron austenitized at $1020^{\circ} \mathrm{C}$ and held at $760^{\circ} \mathrm{C}$, duration $960 \mathrm{~s}:$ (a) lattice fragmentation, (b) spheroidization of network fragments, TEM imaging

As the isothermal holding time becomes longer, the reaction is largely continued in a metastable system (Fig. 9a). The eutectoid cementite causes graphitization and spheroidization especially at the ferrite/pearlite boundary. The F/P boundary loses its definition. The observed increase in ferrite is largely caused by intermediate graphitization (Fig. 9b).

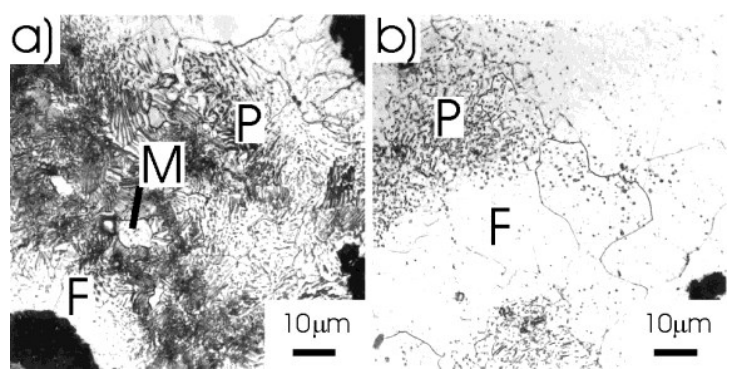

Fig. 9. Micrograph of cast iron austenitized at $960^{\circ} \mathrm{C}$ and held at $760^{\circ} \mathrm{C}$, duration (a) $1800 \mathrm{~s}$, (b) $6 \mathrm{~h}, \mathrm{LM}$

The austenitizing temperature does not affect the location of the ferrite formed during holding. The ferrite crystallized during holding at a temperature approximate to $A_{r 11}$ is most often present as isolated grains without contact with graphite. The ferrite from the eutectoid reaction during isothermal holding right below the temperature $\mathrm{A}_{\mathrm{r} 11}$ grows up to the austenite/graphite boundary and forms ferrite halos in time.

The metallographic quantitative examinations were used to plot the contents of ferrite, pearlite and secondary cementite as a function of isothermal holding time at $820^{\circ} \mathrm{C}$ (Fig. 10) and $760^{\circ} \mathrm{C}$ (Fig. 11).

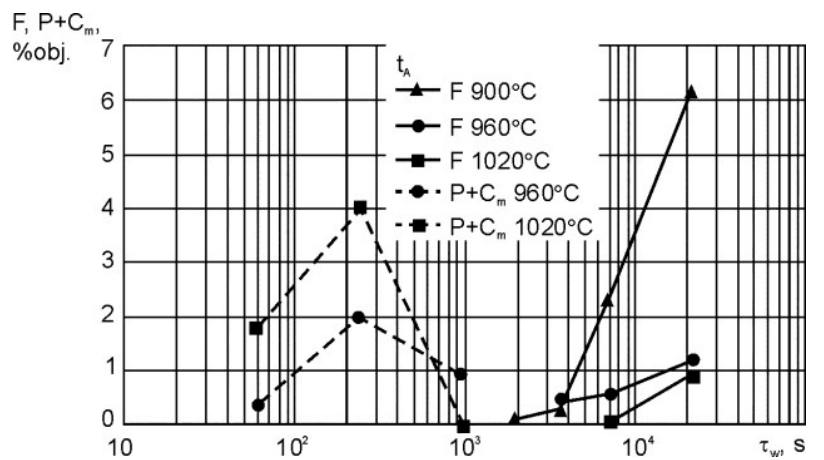

Fig. 10. Contents of ferrite $(\mathrm{F})$, pearlite $(\mathrm{P})$ and networked cementite $\left(\mathrm{C}_{\mathrm{m}}\right)$ vs. cast iron isothermal holding time at $820^{\circ} \mathrm{C}$

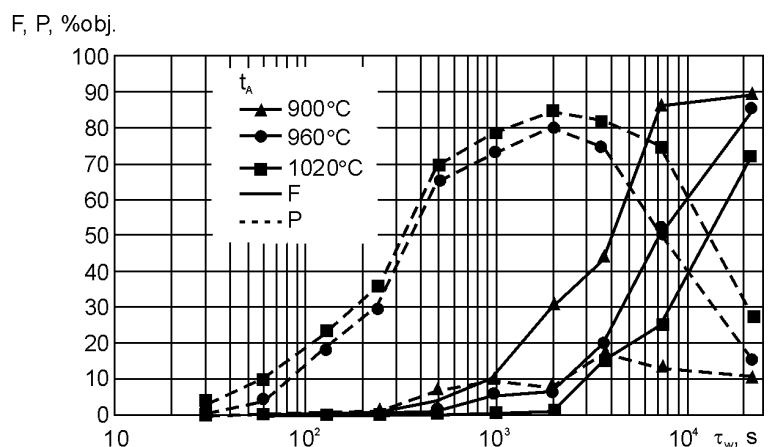

Fig. 11. Contents of ferrite (F) and pearlite (P) vs. isothermal holding time at $760^{\circ} \mathrm{C}$ of the cast iron austenitized at 900,960 or $1020^{\circ} \mathrm{C}$

The overall degree of eutectoid reaction $\eta$, which is the sum of ferrite and pearlite contents during holding at $760^{\circ} \mathrm{C}$, is shown in Fig. 12. The overall reaction degree in the cast iron held at $820^{\circ} \mathrm{C}$ corresponds with the ferrite contents, since the initially crystallized pearlite is unstable and decays before the stable system eutectoid reaction begins (Fig. 10).

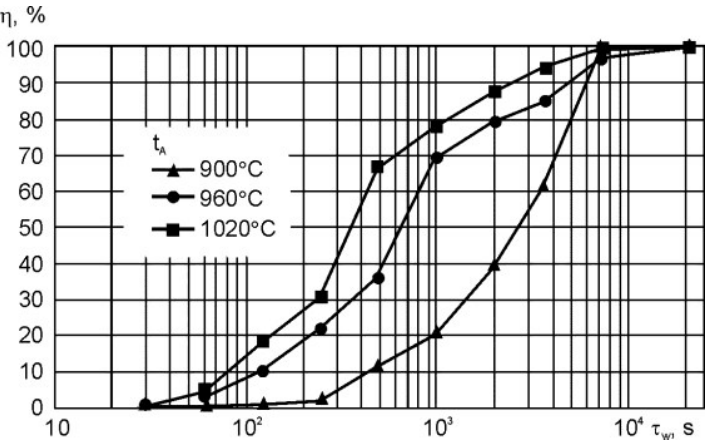

Fig. 12. Overall degree of eutectoid reaction $\eta$ for the cast iron during isothermal holding at $760^{\circ} \mathrm{C}$

The relationship between the ferrite volume content and the isothermal holding time at $760^{\circ} \mathrm{C}$ was approximated with the Avrami equation [18].

Fig. 13 shows the result of the approximation of ferrite quantitative content at the coordinates $\ln \tau-\ln \left[-\ln \left(1-\eta_{\mathrm{f}}\right)\right]$. The Avrami equation constant $\mathrm{k}$ and $\mathrm{n}$ values are listed in Table 3.

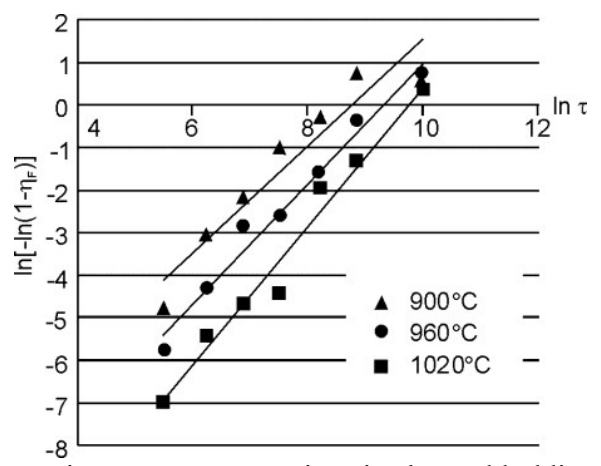

Fig. 13. Ferrite content vs. cast iron isothermal holding time at $760^{\circ} \mathrm{C}$ 
Table 3.

Avrami constant values

\begin{tabular}{cccc}
\hline $\mathbf{t}_{\mathbf{A}},{ }^{\circ} \mathbf{C}$ & $\mathbf{n}$ & $\mathbf{k}$ & $\mathbf{R}^{\mathbf{2}}$ \\
\hline 900 & 1.2673 & -11.086 & 0.9363 \\
\hline 960 & 1.4181 & -13.198 & 0.9775 \\
\hline 1020 & 1.6209 & -15.791 & 0.9605 \\
\hline
\end{tabular}

The cast iron austenitized at $900^{\circ} \mathrm{C}$ and isothermally held $760^{\circ} \mathrm{C}$ has the majority of ferrite formed by the eutectoid reaction of $\mathrm{A} \rightarrow \mathrm{F}+\mathrm{G}$. The cast iron austenitized at $960^{\circ} \mathrm{C}$ or $1020^{\circ} \mathrm{C}$ has the majority of ferrite formed by intermediate graphitization.

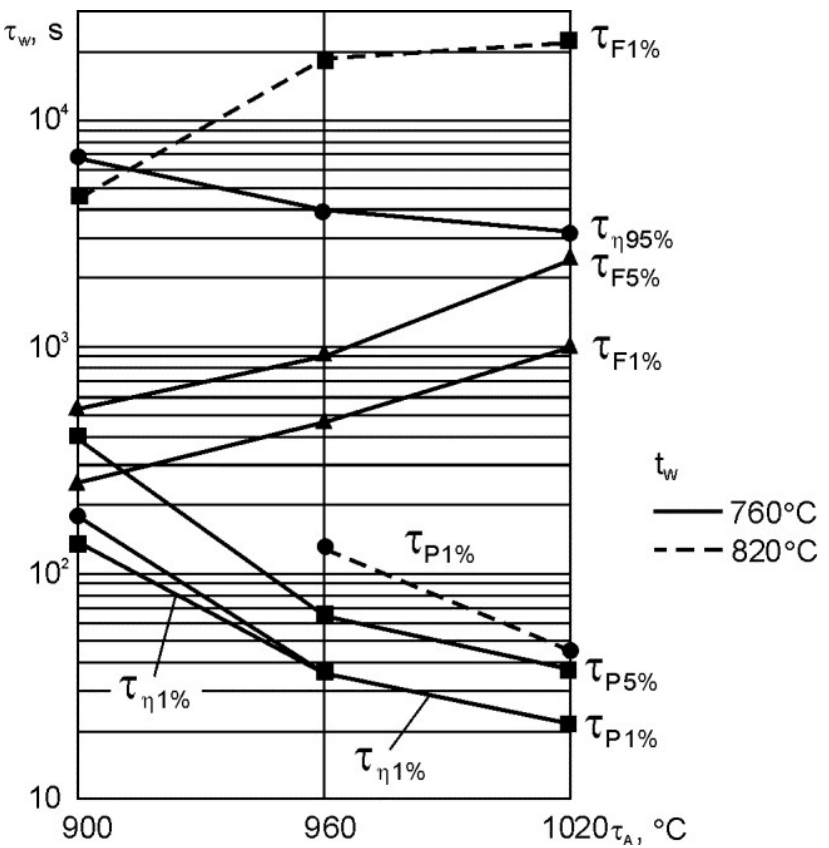

Fig. 14. Time required to achieve the specific transformation phase as a function of austenitizing temperature

Based on the interpolated results of the metallographic quantitative analysis, the times were calculated for the necessary duration of transformation of the austenite into $1 \%$ of ferrite, $5 \%$ of ferrite, $5 \%$ of pearlite, and $1 \%$ or $95 \%$ of the overall reaction degree $\eta$ at $760^{\circ} \mathrm{C}$, and the necessary duration of austenite transformation to $1 \%$ of ferrite or $1 \%$ of transient pearlite during precooling at $820^{\circ} \mathrm{C}$. The specific time values relative to the austenitizing temperature are shown in Fig. 14.

The figure reveals a general pattern in the effect of austenitizing temperature on the eutectoid reaction kinetics. Increasing the austenitizing temperature extends the time necessary to produce $1 \%$ of ferrite during holding at a temperature approximate to $\mathrm{A}_{\mathrm{r} 11}\left(820^{\circ} \mathrm{C}\right)$ and reduces the time necessary to form $1 \%$ of transient pearlite. This means that the time necessary to produce $1 \%$ of the overall reaction degree $\eta$ is also extended, since the only stable and persistent product of the transformation occurring under the contemplated conditions is eutectoid ferrite (supercooled austenite $\rightarrow$ ferrite + graphite).
Increasing the austenitizing temperature extends the time necessary to produce $1 \%$ of ferrite during holding at a temperature approximate to $\operatorname{Ar}_{r} 2\left(760^{\circ} \mathrm{C}\right)$ and reduces the time necessary to form $1 \%$ of pearlite. If the austenite transformation (reaction) degree $\eta$ is the sum of ferrite and pearlite volumes, a temperature increase results in reduction of the time to reach $1 \%$ of reaction degree $\eta$ (transformation start) and reduces the time to reach $95 \%$ of the transformation.

The observed relationship between the characteristic transformation times in the stable system $(\mathrm{A} \rightarrow \mathrm{F}+\mathrm{G})$ or the metastable system $\left(\mathrm{A} \rightarrow \mathrm{F}+\mathrm{Fe}_{3} \mathrm{C}\right)$ should be correlated directly with the input carbon content of austenite, and this parameter is the result of the austenitizing temperature. Higher austenitizing temperatures, i.e. higher input carbon content in supercooled austenite, requires diffusive offtake of more carbon to start the $\mathrm{A} \rightarrow \mathrm{F}+\mathrm{G}$ transformation. Increasing the austenitizing temperature also increases the austenite to cementite supersaturation, and this triggers the precipitation of secondary cementite and the pearlitic transformation.

The process of nucleation of individual phases and structural constituents during a eutectoid reaction depend heavily on structural segregation and chemical microheterogeneity. As-cast CI features $0.4 \% \mathrm{v} / \mathrm{v}$ of cementite, which is most often globular and distributed in the eutectic grain boundary areas. The linear Xray microanalysis reveals elevated manganese and phosphorus contents, localized carbon level maxima and reduced silicon contents in secondary cementite, pearlite and the cementite grains, undissolved during austenitizing and formed during the original crystallization process (Fig. 15).

The distribution of elements along the analytical line drawn right across the martensite reveals elevated contents of manganese, phosphorus and carbon in the interface microareas of eutectic grains, and elevated silicon contents at graphite precipitates. This is a specific microsegregation system in nonalloy ductile cast iron $[6,19]$.

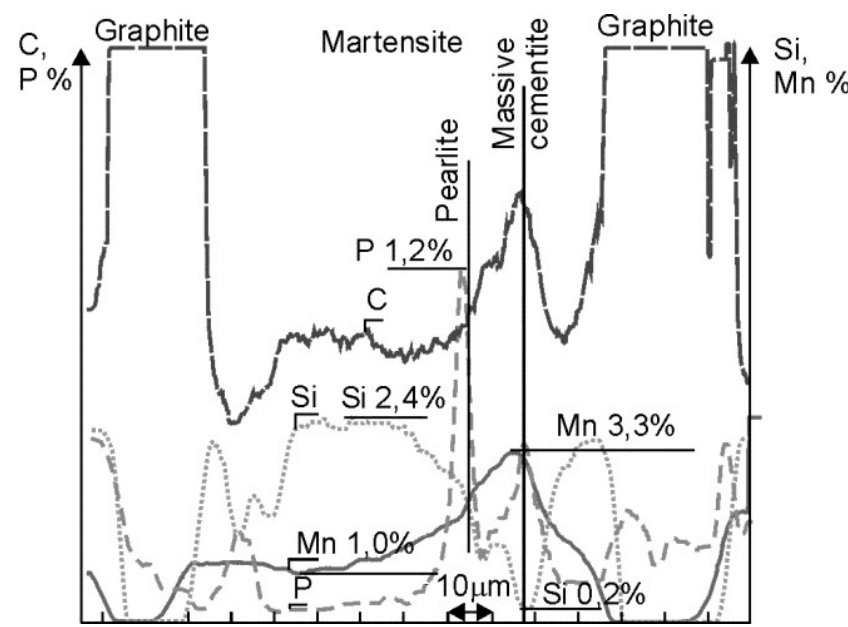

Fig. 15. Distribution of $\mathrm{C}, \mathrm{Mn}, \mathrm{Si}$, and $\mathrm{P}$ in a sample of cast iron austenitized at $900^{\circ} \mathrm{C}$ and held at $760^{\circ} \mathrm{C}$ over $120 \mathrm{~s}$ 


\section{Conclusion}

Based on the test and examination results and the analysis thereof the following general conclusions can be made:

- The austenitizing temperature of cast iron defines both the types of pre-eutectoid precipitates and the formation kinetics of eutectoid reaction products.

- $\quad$ The ferrite nucleation site largely depends on the cooling (holding) temperature.

- The pearlite nucleation site does not depend on the austenitizing temperature or the isothermal holding temperature. It is located at the interface areas of eutectic grains, which is favoured by the microsegregation system of $\mathrm{Ci}, \mathrm{Si}, \mathrm{Mn}$ and $\mathrm{P}$ within the CI matrix and the presence of massive cementite particles which are not dissolved by austenitizing.

- In the cast iron austenitized at elevated temperatures (960 or $1020^{\circ} \mathrm{C}$ ), the eutectoid reaction is preceded by precipitation of surplus carbon from austenite. The precipitate forms secondary latticed cementite.

- Increasing the austenitizing temperature reduces the time to the start of the metastable transformation and extends the time to start the stable eutectoid reaction.

- Understanding the graphitization kinetics of eutectoid cementite in cast iron materials held for cooling down right below $A_{r 1}$ helps choose the time that guarantees the required ferrite to pearlite quantitative ratio.

\section{References}

[1] Darwish, N. \& Eliot, R. (1993). Austempering of low manganese ductile irons. Material Science and Technology. 9(7), 586-602.

[2] Trepczyńska-Łent, M. \& Dymski, S. (2005). The outlook upon austenitising the matrix of ductile iron. Archives of Foundry. 5(17), 353-364. PAN -Katowice PL ISSN 16425308.

[3] Ogi, K., Sawamoto, A., Jin, Y.C. \& Loper, Jr. C.R. (1989). Untersuchungen einiger Aspekte des Austenitisierungs prozesses bei Gusseisen mit Kugelgraphit. Giesserei-Praxiss. 6, 73-79.

[4] Szykowny, T. (2001). Influence of austenitization temperature on $\mathrm{Ar}_{1}$ transformation in plain spheroidal cast iron. Acta Metallurgica Slovaca. 7, 89-93.

[5] Oleszycki, H. (1982). Effect of heating, soaking and cooling on forming pearlitic structure and mechanical properties of unalloyed cast iron. Bydgoszcz: Dissertations no. 7, Section of publishing houses ATR Bydgoszcz (in Polish).

[6] Podrzucki, C. (1991). Cast: structure, properties, applications, Volume 1. Kraków: ZG STOP. (in Polish).

[7] Bermont,V.M. \& Sikora, J.A., (1998). Metallographic study on the influence of the morphology and distribution of graphite on the solid state transformations of grey and ductile cast iron. Int. J. Cast Metals Res. 11, 51-61

[8] Szykowny, T., Sadowski, J. \& Ciechacki, K. (2006). The role of cementite secondary cracking of ductile iron. Archives of Foudry. 6(18), 77-82. (in Polish).

[9] Okumoto, T., Hasegawa, K. \& Tanikawa, M. (1971). Improving the me-chanical properties of pearlitic ductile iron by two-step normalizing. Trans. Amer. Foundrymen's Soc. 79, 473-478.

[10] Fraś, E., Kapturkiewicz, W., Burbelko, A.A. \& Lopez, H.F. (2001). Modelling of phase transformation in ductile cast iron. Archives of Foundry. 1(1), 103-111. (in Polish).

[11] Hazotte, A., Santos, H. \& Lacaze, J. (2003). Austenite/ferrite isothermal reaction in a $0.4 \% \mathrm{Mn}$ spheroidal graphite iron. Int. J. Cast Metals Res. 16, 155-160.

[12] Hellal, F., Lacaze, J. \& Hazotte, A. (1999). Initial stage of isothermal decomposition of austenite to ferrite and graphite in spheroidal graphite cast iron. Materials Science and Technology. 15, 773-777.

[13] Röhrig, K. (1988). Ferritisierung und Perlitisierung in grauen Gusseisenwerkstoffen. Giesserei-Praxis. 8, 101-114.

[14] Lacaze, J. \& Gerval, V. (1998). Modelling of the Eutectoid Reaction in Spheroidal Graphite Fe-C-Si Alloys. ISIJ International. 38(7), 714-722.

[15] Ikhlef, A., Barreau, G., Cizeron, G. \& Gueret, G. (1982) Evolutions Structurales AT Fontes G.S. Au cours de different types de traitements themiques. Hommes et fonderie 1, 9-22 (in French).

[16] Giršovič, N.G. (1978). Sprawočnik po čugunnuju litju. Leningrad: Izd. Mašinostroenie (in Russisch).

[17] Oleszycki, H. \& Sadowski, J. (1998). The structural heterogeneity in blooms test unalloyed ductile iron. Zeszyty Naukowe. Mechanika / Akademia Techniczno-Rolnicza im. Jana i Jędrzeja Śniadeckich w Bydgoszczy. 42(212), 55-73. (in Polish).

[18] Christian, J.W., (1975). Theory of Transformations in Metals and Alloys. 2nd edition, Pt. 1, Pergamon Press Oxford.

[19] Schissler, J.M, Le Dily, D. \& Chobaut, J.P. (1988). Structures Dual-Phase dans les fontes à graphite spehéroïdal, Hommes et Fonderies. 188, 9-15. (in French). 